\title{
Effect of Echinacea purpurea (Asteraceae) aqueous extract on antibody response to Bothrops asper venom and immune cell response
}

\author{
Fernando Chaves ${ }^{1}$, Mauricio Chacón ${ }^{2}$, Beatriz Badilla ${ }^{2} *$ \& Carolina Arévalo ${ }^{2}$ \\ Instituto Clodomiro Picado, Facultad de Microbiologia, Universidad de Costa Rica, 2060, Costa Rica. \\ 2 Instituto de Investigación Farmacéutica, INIFAR, Facultad de Farmacia, Universidad de Costa Rica, 2060, Costa Rica; \\ *bbadilla@cariari.ucr.ac.cr
}

Received 31-I-2003. Corrected 19-IV-2006. Accepted 24-X-2006.

\begin{abstract}
The effect of aqueous extract of Echinacea purpurea roots on the murine antibody response to Bothrops asper snake venom in vivo was studied. Three groups were used. Group \#1, baseline control, was treated with snake venom plus PBS. Group \#2 was treated with snake venom plus sodium alginate as adjuvant (routine method used at Instituto Clodomiro Picado), and group \#3 or experimental group, was treated with snake venom plus aqueous extract of $E$. purpurea root as adjuvant. In all groups, the first inoculation was done with Freund's complete adjuvant (FCA). By the time of the second bleeding, mice in group \#3 showed a remarkable increment in the level of anti-venom antibodies compared with those in groups \#1 or \#2. In vitro immune cell proliferation as a response to aqueous extract of E. purpurea root was studied using human lymphocytes activated with different lectins (Con A, PHA and PWM). In all cases, increase in percentage of lymphoproliferation was greater when E. purpurea root extract was used in addition to individual lectins. Rev. Biol. Trop. 55 (1): 113-119. Epub 2007 March. 31.
\end{abstract}

Key words: Echinacea purpurea, immunostimulatory properties, adjuvant, plant extract, in vitro lymphoproliferation, murine antivenom antibodies.

Echinacea purpurea root is commonly used around the world for stimulation of immune system (Redondo 2000). It is used as herbal medicine in respiratory infections, against malignant tumors and several inflammatory conditions (Elsasser-Beile et al. 1996, Hill et al. 1996, Burger et al. 1997, Percival 2000, Redondo 2000). Some of the active compounds of Echinacea have been identified, such as alkylamides, chicoric acid, arabinogalactan, glycoproteins and polysaccharides. The proportions of these components differ depending on the part of the plant analyzed (Bodinet et al. 1993, Facino et al. 1995, Redondo 2000).

Different researchers have shown that this plant can be used as enhancer of the immune response, specially of cells such as neutrophils, monocytes and lymphocytes (Stotzem et al. 1992, Schoneberger 1992, Bodinet et al. 1993, Miller 1998). Rehman et al. (1999), and Bodinet and Freudenstein (1999) have shown that extracts of Echinacea are able to increase the titer of specific antibodies against antigens, such as keyhole hemocyanin and sheep red blood cells, in the sera of treated animals. Redondo (2000) proposes that this plant stimulates the acquired immune system because of its specific action on lymphocytes, enhancing the production of antibodies and $\mathrm{T}$ cell responses. Other investigators have indicated that root extracts from Echinacea are able to stimulate the production of cytokines, such as IL-1, IL-10 and TNF- $\alpha$ by human macrophages (Burger et al. 1997).

At Instituto Clodomiro Picado, we use the venom of Bothrops asper, together with, those 
of Crotalus durissus and Lachesis stenophrys, as an immunization mixture in the production of horse polyvalent antiserum for the treatment of pit viper bites (Bolaños and Cerdas 1980, Gutiérrez et al. 1988, Gutiérrez 2002). B. asper (commonly known as "terciopelo") is the most important venomous snake in Central America from the standpoint of human mortality and morbidity causing the majority of envenomations in these countries (Bolaños 1982, Campbell and Lamar 1989, Hardy 1994, Rojas et al. 1997, Arroyo et al. 1999, Sasa 2002).

In this work, we investigated the use of $E$. purpurea root extract to improve the in vivo anti-venom humoral immune response of mice immunized with $B$. asper venom. In addition, we studied the in vitro effect of this extract on the mitogenic response of human lymphocytes to different lectins (PHA, PWM and Con A).

\section{MATERIALS AND METHODS}

Snake venom: it was obtained from adult specimens of $B$. asper collected in the Pacific region of Costa Rica. Venom pools were made from more than 40 individual snakes. After lyophilization, the venom was maintained at $-20{ }^{\circ} \mathrm{C}$. This process is routinarily used at Instituto Clodomiro Picado, Universidad de Costa Rica.

Plant extract: crude powder of E. purpurea root was kindly provided by "Industria Los Patitos, S.A.", Heredia, Costa Rica. A $10 \%$ aqueous extract was prepared by infusion with $70{ }^{\circ} \mathrm{C}$ water for $30 \mathrm{~min}$. This extract was filtered, vacuum concentrated, lyophilized and kept in dark bottles at $4{ }^{\circ} \mathrm{C}$ until used.

Experimental animals: female White Swiss Webster mice (18-20 gm), supplied by Instituto Clodomiro Picado were used.

Human white blood cells: peripheral blood mononuclear cells (PBMC)) were obtained from anti-coagulated human blood using a Ficoll-Hypaque (Sigma, St. Louis, MO) gradient. In the case of lymphoproliferation experiments, human blood from young male volunteers 20-25 years old, was used.
Immunization protocol: for murine experiments, the immunization protocol used was based on the one described by Rucavado et al. (1996), with slight modifications. Three groups were established: Group \#1 (baseline control) treated with snake venom plus $0.1 \mathrm{M}$ phosphate buffered saline pH 7.2 (PBS). Group \#2 was treated with snake venom plus sodium alginate as adjuvant (routinary method used at Clodomiro Picado). Group \#3, experimental group, was treated with snake venom plus aqueous extract of Echinacea purpurea root as adjuvant. During the first immunization, all groups received a subcutaneous (sc) injection of venom $(20 \mu \mathrm{g}$ in $100 \mu \mathrm{l}$ PBS $)$, emulsified in an equal volume of Freund's Complete Adjuvant (FCA). Following the first immunization, at two week intervals, each group received sc injections of increasing amounts of venom $(20,40$ and $60 \mu \mathrm{g}$ each diluted in $100 \mu 1$ PBS) using as adjuvants either an equal amount of sodium alginate or Echinacea root extract (groups \#2 or \#3 respectively). In group \#1 (baseline control), the first venom dose was emulsified with FCA. The rest of immunizations were administered with PBS alone (no adjuvant).

After the fourth immunization, mice were tail bled at two weeks intervals. One week after each bleeding, additional injections of $40 \mu \mathrm{g}$ venom, with the corresponding adjuvant, were performed. From the first immunization until the first bleeding, group \#3, was injected with 100 $\mu \mathrm{g}$ of Echinacea extract. Thereafter, Echinacea dose was increased to $200 \mu \mathrm{g}$ of extract.

Enzyme linked immunosorbent assay (ELISA): the change in antibody levels was measured by enzyme linked immunosorbent assay (ELISA). $100 \mu \mathrm{l}$ of venom suspension (1 $\mu \mathrm{g} / 100 \mu \mathrm{l}$ in PBS with $2 \%$ BSA) were placed in each well of 96 well plates (Dynatech, Immulon II) and incubated overnight at $4{ }^{\circ} \mathrm{C}$. Plates were washed three times with PBS immediately before use. A 1/2000 dilution of each serum was added by triplicate, incubated at room temperature for one hour and washed as described before. Normal mouse serum was used as control. Bound antibodies were 
detected using an anti-mouse- $\operatorname{IgG}$ antiserum peroxidase-conjugated (Sigma). O-phenylenediamine (Sigma) was used as substrate, color development was directly proportional to $\mathrm{IgG}$ concentration. Absorbances were recorded at $492 \mathrm{~nm}$ (Dynatech 500).

Mitogenic response of human lymphocytes: lymphocytes were obtained from anticoagulated human blood using a Ficoll-Hypaque (Sigma, St. Louis, Mo.) gradient. After washing twice with RPMI (GIBCO), the cells were resuspended to $5 \times 10^{6}$ cells $/ \mathrm{ml}$ in RPMI plus $10 \%$ fetal calf serum (FCS), $100 \mu 1$ of this cell suspension were placed in each well.

Lymphocytes were stimulated with aqueous extract of E. purpurea at different final concentrations. Three lectins (PHA, Con A, PWM) in three different concentrations each, were tested separately as costimulant molecules required for this assay. PHA final well concentrations were: $0.5,5.0$ and $10.0 \mu \mathrm{g} / \mathrm{ml}$. PWM final well concentrations were 2.5, 5.0 and 10.0 $\mathrm{ng} / \mathrm{ml}$. Con A final well concentrations were 2.5, 5.0 and $10.0 \mu \mathrm{g} / \mathrm{ml}$. Final concentration of Echinacea extract was also varied using serial dilutions (final well concentrations: $0 ; 4 ; 8 ; 16$; $33 ; 66 ; 133 ; 266 \mu \mathrm{g} / \mathrm{ml})$. Lymphocytes in the presence of Echinacea extract and lectin were incubated during four days at $37^{\circ} \mathrm{C}, 5 \% \mathrm{CO}_{2}$, $80 \%$ humidity in a Cole Parmer $\mathrm{CO}_{2}$ incubator. After incubation, $25 \mu$ of 3-[4-5-dimethylthiazol-2-yl] 2,5 diphenyl-tetrazolium bromide (MTT) (Sigma, St. Louis, MO) were added to each well followed by 4 additional hours of incubation at $37{ }^{\circ} \mathrm{C}$. Reaction was stopped adding $50 \mu \mathrm{l}$ SDS $20 \%$ in dimethylformamide $\mathrm{pH}$ 4.7. Absorbances were recorded at $550 \mathrm{~nm}$ (Biorad Microplate Reader Model 550).

Percentage of proliferation obtained with lectins alone (no addition of Echinacea extract), was established as $100 \%$ and used as experimental control. Percentage of proliferation obtained with lectin plus Echinacea extract was calculated by dividing the absorbance of the experimental well (lectin plus Echinacea) by the absorbance of the control well (lectin alone) and multiplying by 100 . If the percentage obtained was significantly higher than
$100 \%$, the extract was considered stimulatory. Likewise, if it was significantly lower than $100 \%$, it was considered inhibitory of lymphocyte proliferation.

Statistical analyses: results are presented as the mean \pm standard deviation. Statistical significance of the differences in mean absorbances between experimental groups was performed by one-way analysis of variance, and the significant differences $(p<0.05)$ were compared by Tukey-Kramer multiple comparison test.

\section{RESULTS}

Antibody production: antibody levels corresponding to first bleeding (two weeks after 4th immunization) and second bleeding (four weeks after 4th immunization) are shown in Figure 1. At the moment of the first bleeding, mice in group \#3 (venom plus E. purpurea root extract), had a slightly higher level of antibodies (no significant difference) than mice in Groups \#1 or \#2.

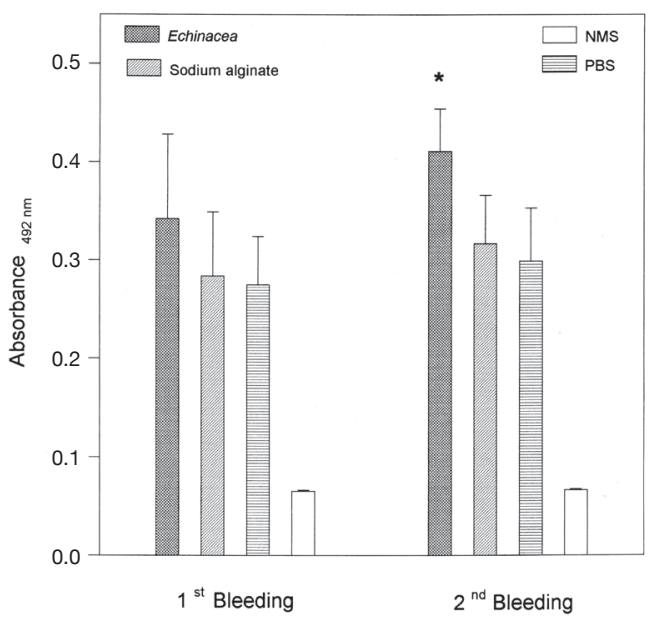

Fig. 1. Specific anti-venom antibody levels in sera of mice injected with Bothrops asper venom and different adjuvants. Mice receiving injections of venom plus Echinacea extract (Echinacea) showed higher levels of specific antibody than mice injected with venom plus sodium alginate (Sodium alginate) or PBS (PBS). Baseline levels of antibody in normal mice sera are shown (NMS). Results are shown as mean $+\mathrm{SD}$ of absorbances obtained from the ELISA test $(* \mathrm{p}<0.05)$. 
At the time of the second bleeding, group \#3 developed a higher antibody titer (a statistically significant), compared to the other groups tested (Fig. 1). Group \#2, did not improve antibody levels, compared to mice in group \#1 (Fig. 1).

Lymphocyte mitogenic response: Stimulation of human lymphocyte cultures with PWM and Echinacea shows an increase in cell proliferation at PWM concentrations of 2.5

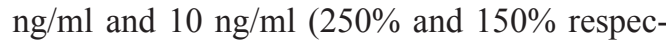
tively) (Fig. 2), compared to growth of lymphocytes with PWM and no Echinacea extract. Using PWM $5 \mathrm{ng} / \mathrm{ml}$ there was no significant change in level of proliferation.

In lymphoproliferation assays using PHA plus Echinacea, we observed an increase in lymphocyte proliferation at all of the lectin concentrations used $(0.5 ; 5.0$ and $10 \mu \mathrm{g} / \mathrm{ml})$. The best stimulation (431\%) was achieved with 10 $\mu \mathrm{g} / \mathrm{ml}$ of PHA at $4 \mu \mathrm{g} / \mathrm{ml}$ of Echinacea extract (Fig. 3). Using PHA $5 \mu \mathrm{g} / \mathrm{ml}$ and Echinacea extract at $4 \mu \mathrm{g} / \mathrm{ml}$, we obtained $282 \%$ of stimulation. With $0.5 \mu \mathrm{g} / \mathrm{ml}$ of PHA and $66 \mu \mathrm{g} / \mathrm{ml}$ of Echinacea extract, we obtained $215 \%$ stimulation (Fig. 3).

Concerning experiments with Con A and Echinacea extract (Fig. 4), percentage of cell

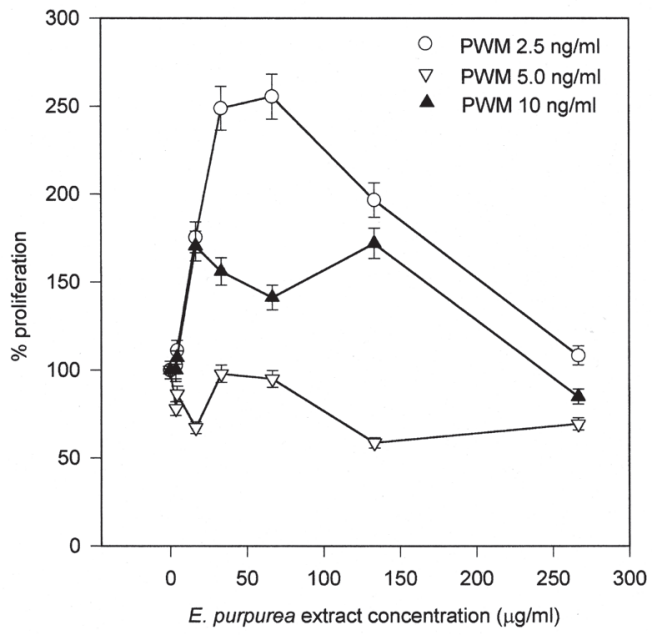

Fig. 2. Effect of aqueous extract of Echinacea purpurea plus PWM on lymphoproliferation in vivo. Human lymphocytes were cultured in the presence of PWM (2.5, 5.0 and 10 $\mathrm{ng} / \mathrm{ml}$ respectively) and Echinacea purpurea root extract. Results are shown as mean + SD. growth was slightly stimulated (158\%) at Con A concentrations of $2.5 \mu \mathrm{g} / \mathrm{ml}$ and Echinacea $34 \mu \mathrm{g} / \mathrm{ml}$. At Con A $5.0 \mu \mathrm{g} / \mathrm{ml}$ and Echinacea $16 \mu \mathrm{g} / \mathrm{ml}$, a slight but not significant (128\%) increase was observed. At $10 \mu \mathrm{g} / \mathrm{ml}$ of Con A, there was a decrease in percentage of proliferation up to $28 \%$ at an Echinacea concentration of $66 \mu \mathrm{g} / \mathrm{ml}$.

Figure 5 shows results of the highest lymphoproliferation obtained with each one of the three different lectins. The lectin concentrations shown are PWM 2,5 ng/ml, PHA $10 \mu \mathrm{g} / \mathrm{ml}$ and Con A $10 \mu \mathrm{g} / \mathrm{ml}$. In all cases, best results were obtained at concentrations of Echinacea lower than $100 \mu \mathrm{g} / \mathrm{ml}$. At higher Echinacea concentrations the lymphoproliferation response was milder or nule. PHA increased lymphocyte proliferation up to approximately $400 \%$ and PWM stimulated lymphochyte proliferation up to approximately $250 \%$.

\section{DISCUSSION}

In studies accomplished by Rucavado et al. (1996) the adjuvant properties of various immunostimulants (sodium alginate, calcium alginate, aluminum hydroxide and muramyl

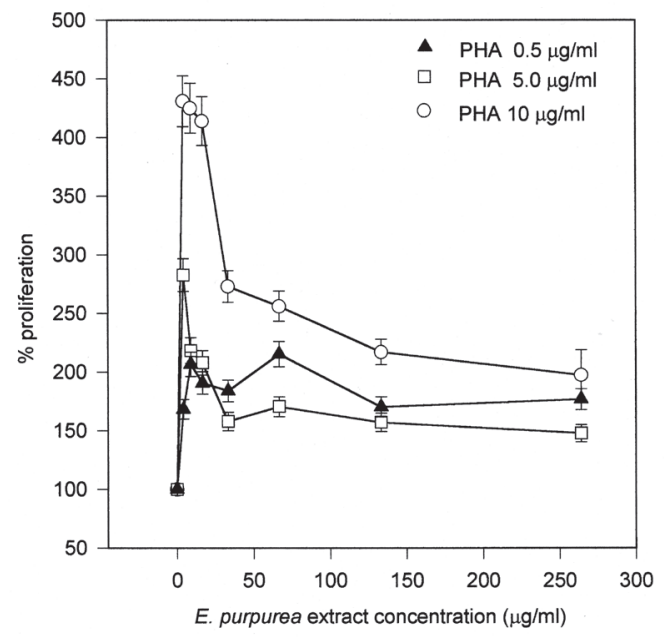

Fig. 3. Effect of aqueous extract of Echinacea purpurea plus PHA on lymphoproliferation in vivo. Human lymphocytes were cultured in the presence of PHA $(0.5,5.0$ and $10.0 \mu \mathrm{g} / \mathrm{ml}$ respectively) and Echinacea purpurea root extract. Results are shown as mean + SD. 


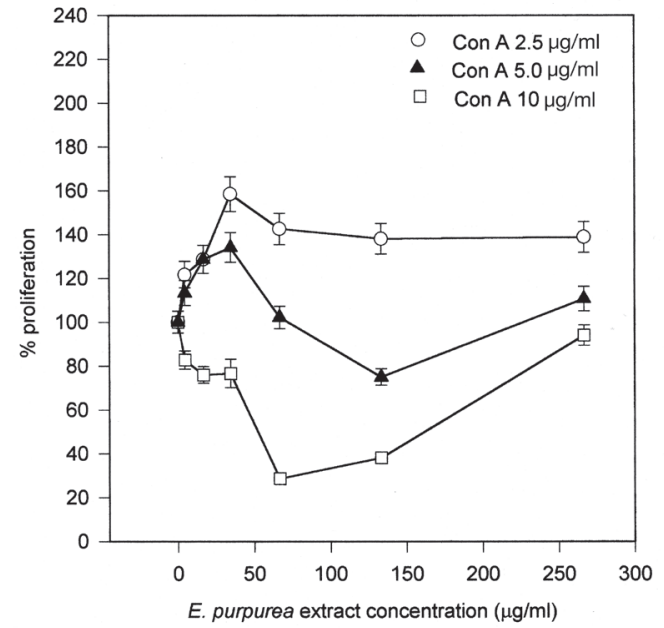

Fig. 4. Effect of aqueous extract of Echinacea purpurea plus Concanavalin A on lymphoproliferation in vivo. Human lymphocytes were cultured in the presence of Con A (2.5, 5.0 and $10.0 \mu \mathrm{g} / \mathrm{ml}$ respectively) and Echinacea purpurea root extract. Results are shown as mean $+\mathrm{SD}$.

dipeptide) on murine antibody response against B. asper were evaluated. They found that the level of immunopotentiation obtained by all of these molecules was very similar. The purpose of this research was to determine if the aqueous extract of $E$. purpurea roots had adjuvant properties on immune response to snake poisons, which might be applied in the industrial production of anti-venom antiserum.

Researchers have shown that extracts from different parts of Echinacea sp. are able to increase both specific and non-specific immune response, such as activation of neutrophils, macrophages, $\mathrm{T}$ and $\mathrm{B}$ cells (Stotzem et al. 1992, Bodinet et al. 1993, Facino et al. 1995, Rehman et al. 1999, Bodinet and Freudenstein 1999). See et al. (1997) and Percival (2000) suggest that Echinacea affects only the phagocytic immune system, specifically acting on macrophages and neutrophils. It is possible that there are different costimulatory molecules present in Echinacea extracts tested (Bodinet et al. 1993, Redondo 2000). We suggest that B cell activation is due to the presence of polysaccharides, such as arabinolactanes, which act as polyclonal activators.

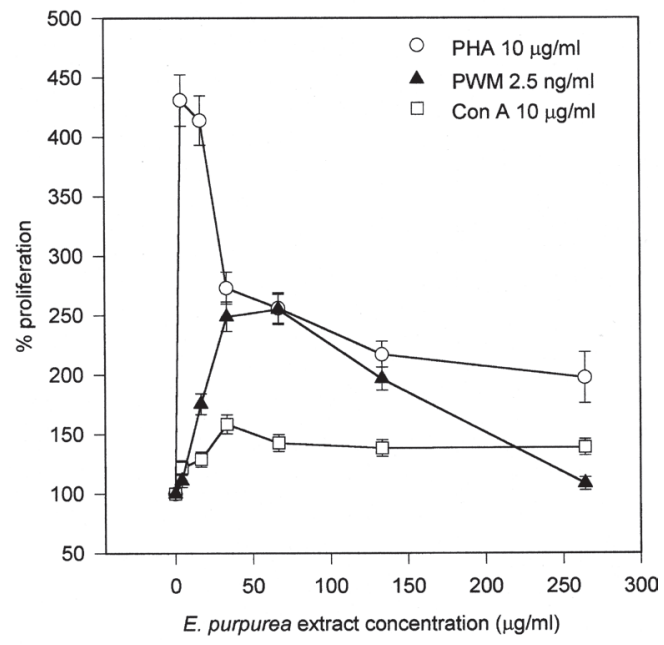

Fig. 5. Summary of effects of aqueous extract of Echinacea purpurea plus different lectins on lymphoproliferation in vivo. Human lymphocytes were cultured in the presence of different lectins (Con A $10 \mu \mathrm{g} / \mathrm{ml}$, PHA $10 \mu \mathrm{g} / \mathrm{ml}$ or PWM $2.5 \mathrm{ng} / \mathrm{ml}$ ) and Echinacea purpurea root extract. Results are shown as mean $+\mathrm{SD}$.

In this work, we demonstrate that the aqueous extract of Echinacea roots stimulates proliferation of human lymphocytes in vitro and is able to increase specific antibody response in vivo. We show that E. purpurea root extract is $30 \%$ more potent than sodium alginate with respect to stimulation of anti-venom antibodies, and it can be used together with other adjuvants (e.g. Freund's).

Results indicate that there is a conspicuous difference in the anti-venom antibody levels in mice treated with Echinacea compared with mice treated with PBS or sodium alginate alone. During the first stage of the immunization schedule, the difference between antibody levels of mice treated with Echinacea compared to the other experimental groups was very slight. After the second bleeding, the immune response of mice injected with Echinacea reached much higher levels than the other two groups.

We performed the in vitro lymphoproliferation assays in order to test if Echinacea extract was acting directly as a mitogen of immune cells. By using the different lectins we were trying to determine if Echinacea 
root extract was acting preferentially on a specific population of lymphocytes ( $\mathrm{T}$ or $\mathrm{B}$ cells). PWM is known as a $\mathrm{T}$ and $\mathrm{B}$ cell mitogen while PHA and Con A are mitogens for $\mathrm{T}$ cells. This selectivity is due to the binding of lectins to different sugar radicals on the cell surface. In our experiments, we observed that PHA and PWM stimulated human lymphocyte proliferation in vitro, at concentrations of Echinacea root extract lower than $100 \mu \mathrm{g} / \mathrm{ml}$. We propose that Echinacea root extract is activating proliferation of $\mathrm{T}$ and $\mathrm{B}$ cells. The fact that the Echinacea/Con A combination did not improve lymphoproliferation in a significant manner compared to Echinacea/PHA could be due to the effect of this lectin on a different subpopulation of T cells. This effect could also be due to toxicity of the Echinacea/Con A combination at these specific concentrations. We believe that one or several components present in the plant extract, act as costimulatory molecules, potentiating the mitogenic effect induced by PHA or PWM.

Some researchers have shown that Echinacea extracts are able to promote the production of cytokines such as IL-1, IL-2, TNF, IL-6 and INF- $\gamma$ (Elsasser-Beile et al. 1996, Burger et al. 1997). This ability of Echinacea might contribute to improve the in vivo immune response observed in our experiments.

In conclusion, our observations indicate that the aqueous extract of Echinacea is able to stimulate in vivo the production of antibodies against the specific antigen $B$. asper venom and to stimulate in vitro the proliferation of lymphocytes. We suggest that this extract should be used as immunostimulant in the immunization protocols of animals such as horses during production of antisera (e.g. antiofidic sera).

\section{ACKNOWLEDGMENTS}

We thank "Industria Los Patitos, S.A." for providing E. purpurea ground roots. We also thank Nieng Tzu Weng, Juan Carlos Brenes, Alexis Torres and Marco Méndez for technical support. We thank Gerardo Mora for his support in the use of the facilities of Centro de Investigación en Productos Naturales (CIPRONA). This work was supported by Vicerrectoría de Investigación (Project No. 817-98-515), Universidad de Costa Rica.

\section{RESUMEN}

Se estudió in vivo, el efecto del extracto acuoso de las raíces de Echinacea purpurea en la respuesta de los anticuerpos murinos al veneno de la serpiente Bothrops asper. El grupo 1 control, fue tratado con el veneno y PBS. El grupo 2 con veneno y alginato de sodio (método utilizado en el Instituto Clodomiro Picado), y el grupo 3 o experimental, con veneno y extracto acuoso de las raíces de E. purpurea. En todos los grupos, la primera inmunización fue hecha con FCA (Freund's Complete Adjuvant). En las muestras correspondientes a la segunda sangría, los ratones del grupo 3 mostraron un marcado incremento en el nivel de anticuerpos, en comparación con los ratones de los otros grupos. También se determinó la proliferación de células inmunes in vitro, como respuesta al extracto acuoso de la raíz de E. purpurea, utilizando linfocitos humanos activados con diferentes lectinas (Con A, PHA y PWM). En todos los casos, el incremento en el porcentaje de linfoproliferación fue mayor, cuando estaba presente el extracto de la raíz de E. purpurea.

Palabras clave: Echinacea purpurea, propiedades inmunoestimulatorias, extracto de plantas, linfoproliferación in vitro, anticuerpos de anti-veneno murino.

\section{REFERENCES}

Arroyo, O., G. Rojas \& J.M. Gutiérrez. 1999. Envenenamiento por mordedura de serpiente en Costa Rica en 1996: epidemiología y consideraciones clínicas. Acta Méd. Costarric. 41: 23-29.

Bodinet, C., I. Willigmann \& N. Beuscher. 1993. Hostresistance increasing activity of root extracts from Echinacea species. Planta Med.Suppl. 59: A672A673.

Bodinet, C. \& J. Freudenstein. 1999. Effects of an orally applied aqueous-ethanolic extract of a mixture of Thujae occidentalis herba, Baptisiae tinctoriae radix, Echinacea purpurea radix and Echinacea pallidae radix on antibody response against sheep red blood cells in mice. Planta Med. 65: 695-699.

Bolaños, R. 1982. Las serpientes venenosas de Centroamérica y el problema del ofidismo. Primera parte. Aspectos zoológicos, epidemiológicos y biomédicos. Rev. Cost. Cienc. Méd. 3: 165-184. 
Bolaños, R. \& L. Cerdas. 1980. Producción y control de sueros antiofídicos en Costa Rica. Bol. Ofic. Sanit. Panam. 88: 189-196.

Burger, R.A., A.R. Torres, R.P. Warren, V.D. Caldwell \& B.G. Hughes 1997. Echinacea-induced cytokine production by human macrophages. Int. J. Pharm. 19: 371-379.

Campbell, J.A. \& W.W. Lamar 1989. The venomous reptiles of Latin America. Cornell University, Ithaca, New York, New York, USA. 425 p.

Elsasser-Beile, U., W. Willenbacher, H.H. Bartsch, H. Gallati, J. Schulte Monting \& S. von Kleist. 1996. Cytokine production in leukocyte cultures during therapy with Echinacea extract. J. Clin. Lab. Anal 10: 441-445.

Facino, R.M., M. Carini, G. Aldini, L. Saibene, P. Pietta \& P. Mauri .1995. Echinacoside and caffeoyl conjugates protect collagen from free radical-induced degradation: a potential use of Echinacea extracts in the prevention of skin photodamage. Planta Med. 61: $510-514$.

Gutiérrez, J.M., F. Chaves, E. Rojas, J. Elizondo, C. Avila. \& L. Cerdas 1988. Production of monovalent antiBothrops asper antivenom: development of immune response in horse and neutralizing ability. Rev. Biol. Trop. 36: 511-517.

Gutiérrez, J.M. 2002. Comprendiendo los venenos de serpientes: 50 años de investigaciones en América Latina. Rev. Biol. Trop. 50: 377-394.

Hardy, D.L. 1994. Bothrops asper (Viperidae) snakebite and field researches in Middle America. Biotropica 26: 198-207.

Hill, N., C. Stam \& R.A. van Haselen. 1996. The efficacy of Prikweg gel in the treatment of insect bites: a double-blind, placebo-controlled clinical trial. Pharm World Sci. 18: 35-41.
Miller, L.G. 1998. Herbal medicinals: select clinical considerations focusing on known or potential drug-herb interactions. Arch. Intern. Med. 158: 2200-2211.

Percival, S.S. 2000. Use of Echinacea in medicine. Biochem. Pharmacol. 60: 155-158.

Redondo, L. 2000. La equinácea purpúrea: una alternativa real para estimular el sistema inmunológico. Rev. Fitoterapia 1: 15-24.

Rehman, J., J.M. Dillow, S.M. Carter, J. Chou, B. Le \& A.S. Maisel. 1999. Increased production of antigenspecific immunoglobulins $\mathrm{G}$ and $\mathrm{M}$ following in vivo treatment with the medicinal plants Echinacea angustifolia and Hydrastis canadensis. Immunol. Letters 68: 391-395.

Rojas, G., G. Bogarín, \& J.M. Gutiérrez. 1997. Snakebite mortality in Costa Rica. Toxicon. 35: 1639-1643.

Rucavado, A., E. Moreno \& J.M. Gutiérrez 1996. Effect of adjuvants on the antibody response of mice to Bothrops asper snake venom. Braz. J. Med. Biol. Res. 29: 1337-1340.

Schoneberger, D. 1992. The influence of immune stimulating effects of pressed juice from Echinacea purpurea on the course and severity of colds. Forum Immunol. 8: 2-12.

Sasa, M. 2002. Morphological variation in the lancehead pitviper Bothrops asper (Garman) (Serpentes: Viperidae) from Middle America. Rev. Biol. Trop. 50: 259-271.

See, D.M., N. Broumand, L. Sahl \& J.G. Tilles. 1997. In vitro effects of Echinacea and ginseng on natural killer and antibody-dependent cell cytotoxicity in healthy subjects and chronic fatigue syndrome or acquired immunodeficiency syndrome patients. Immunopharmacology 35: 229-235.

Stotzem, C., U. Hungerland \& U. Mengs 1992. Influence of Echinacea purpurea on the phagocytosis of human granulocytes. Med. Sci. Res. 20: 719-720. 
